\title{
POSSIBILITY OF USING SOME AGRICULTURAL RESIDUALS IN TOMATO NURSERY PRODUCTION
}

\author{
F. E. Zabady, ${ }^{(1)}$ A. M. A.Mashour, ${ }^{(2)}$
}

\author{
A. E. Abd elhameed ${ }^{(3)}$ and R. R. El-Bessoumy ${ }^{(4)}$
}

\begin{abstract}
ABSTRAT
The main objective of this study is possibility of using some agricultural residuals as plant media to tomato nursery. These residues as ground cotton stalks, ground rice straw and ground corn stalks. Each residual contains different ratio of sand. Also, one sample was $75 \%$ peatmoss plus $25 \%$ velrmiculite as a control. Laboratory experiments were conducted to quantify real density $\left(\mathrm{g} / \mathrm{cm}^{3}\right)$, bulk density $\left(\mathrm{g} / \mathrm{cm}^{3}\right)$, hydraulic conductivity $(\mathrm{cm} / \mathrm{min})$, total porosity (\%), and available water $(\mathrm{g} / \mathrm{g})$ as affected by different mixtures experimental. The tomato nursery was planted into trays in greenhouse to study some growth parameters as germination ratio, nursery high, plant weight, and leaves number as affected by different mixtures. The results show that in the media of (sand + ground cotton stalks), (sand + ground rice straw), and (sand + ground corn stalks) decreased sand ratio gave an increased in both total porosity and available water, the highest value of total porosity and available water were at mixture of (20\% sand $+80 \%$ residuals). Also, the highest growth parameter of nursery as nursery weight and nursery high was obtained with the same mixture.
\end{abstract}

\section{INTRODUCTION}

A gricultural residues are the secondary materials which were produced from agricultural processes whether these processes were biological or during improvement shape of product, and these residues may be useful or harmful for human, Abd El-Ghaffar (1987). Alaa El-Din et al. (1983) and El-Zahaby (1996) mentioned that the crops residues are materials that remain after the edible grain, seed,

\footnotetext{
${ }^{(1)}$ Assoc. Prof., Water and Farm Irri.Sys. Eng. Dept., Fac. of Agric. Eng. Cairo, Al-Azhar Univ.

${ }^{(2)}$ Assoc. Prof., Soil and Water Dept., Fac. of Agric., Al-Azhar Univ.

${ }^{(3)}$ Lect. Agric. Produc. Proc. Eng. Dept., Fac. of Agric. Eng. Cairo, Al-Azhar Univ.

${ }^{(4)}$ LectAgric. Struc. and Enviro. Cont. Eng. Dept., Fac. of Agric. Eng. Cairo, Al-Azhar Univ.
} 
fruit, or primary fibers has been removed from plant. It includes straw, stalkss stems, hulls, stovers caps, bagasse and fruit piles, etc. FAO SCHWARZ (2005) mentioned that the total annual Egyptian crop residues about 30 million tons. Nouno (2003) mention that air quality is one of Egypt's more pressing environmental problems, and the smoke from smoldering rice straw pits is one of the major causes of the seasonal, thick, brown smog that hangs over the city scope. The disposal option now accounts for an estimated $90 \%$ of the straw, with the remainder used in fodder or incorporated into the soil.

The first step in successful vegetable production is to raise healthy vigorous seedlings. Young plants whether propagated from seed or vegetative require a lot of care particularly during the early stages of growth. They have to be protected from adverse temperatures, heavy rains, drought, wind and variety of pests and diseases. To overcome these problems many vegetable crops are grow in nurseries before being transplanted in the field seedling media. Soil is the major medium for germination seeds and growing seedlings although it is not the best. There are arterial media made of perlite, vermiculite and peatmoss, which are used as soil substitutes. For best results, a growth rooting medium should possess the following qualities:

sufficient firm enough and dense to hold seeds in place during germination, sufficiently porous to let excess water drain away, have a high water holding capacity, free from weed seeds, nematodes and other pathogens, high cation exchange so that can provide nutrients able to with stand sterilization treatment without being altered, and not be toxic to plants. Since it may not be possible for one medium to have all these characteristics, different media are normally mixed together to obtain a near ideal mixture.

Zabady (2012) studied effect of phsico-hydraulic $n$ tomato nursery he found that in the media of "sand + peatmoss" increased sand ratio gave an increase in total porosity and a decrease in water holding capacity. At mixture of "sand + vermiculite", the total porosity decreased with increase in sand ratio and water holding capacity decreased with an increase in sand ratio. The highest values of total porosity and water holding capacity 
were at mixture of ( $70 \%$ peatmoss $+30 \%$ sand). Also, the highest growth parameter of nursery as seedling weight and length was obtained with the same mixture.

The main objective of this study are using some agriculture residual as straw, ground stalks cotton and ground stalks corn, with sand ratio to obtain nursery media.

\section{MATERIALS AND METHODS}

\section{MATERIALS}

Laboratory Experiments were carried out in the irrigation laboratory, Agricultural Engineering Department, Al-Azhar University, Nasr City, Cairo. The main objectives of the laboratory experiments were the determination of the characteristics of different mixture media samples such as: real density, bulk density, hydraulic conductivity, total porosity, and available water for cultivating the tomato nursery.

Twelve samples and one control were made for mixture which varied in volumetric proportions of residuals and sand. Ground cotton stalks, ground rice straw, and ground corn stalks ratios valid from 50,60, 70, and $80 \%$, therefore the sand ratio from 20 to $50 \%$. The cotton stalk, rice straw, and corn stalk were milled by cutting machine and mixed with sand ratios as shown in table(1).

\section{Tomato:}

Tomato (Lycopersiconesculentum Mill), which is cultivated in trays for home consumption and commercial domestic market, processing plants and exporting is one of the world's most popular vegetables (Fao, 1989). It also possesses valuable medical properties, an excellent purifier other vegetables (Villareal, 1978). Good quality of seedling usually leads to higher yield and earlier maturity. Tomato that matures early not only could receive higher price on fresh market, but also could reduce the risk involved in growing tomatoes in the tropics. The growth parameters were measured as seedling length, leaves number, nursery weight, and germination ratio. 
Table (1): Ratios of sand (\%), ground stalks cotton (\%), ground rice straw $(\%)$, and ground stalks corn $(\%)$ for each treatment in the present study.

\begin{tabular}{|c|c|c|c|c|}
\hline \multirow{2}{*}{ No } & \multicolumn{4}{|c|}{ Residuals ratio } \\
\cline { 2 - 5 } & $\begin{array}{c}\text { Sand } \\
\boldsymbol{\%}\end{array}$ & $\begin{array}{c}\text { Cotton } \\
\boldsymbol{\%}\end{array}$ & $\begin{array}{c}\text { Rice } \\
\boldsymbol{\%}\end{array}$ & $\begin{array}{c}\text { Corn } \\
\boldsymbol{\%}\end{array}$ \\
\hline A & $\mathbf{5 0}$ & $\mathbf{5 0}$ & - & - \\
\hline B & $\mathbf{4 0}$ & $\mathbf{6 0}$ & - & - \\
\hline C & $\mathbf{3 0}$ & $\mathbf{7 0}$ & - & - \\
\hline D & $\mathbf{2 0}$ & $\mathbf{8 0}$ & - & - \\
\hline E & $\mathbf{5 0}$ & - & $\mathbf{5 0}$ & - \\
\hline F & $\mathbf{4 0}$ & - & $\mathbf{6 0}$ & - \\
\hline G & $\mathbf{3 0}$ & - & $\mathbf{7 0}$ & - \\
\hline H & $\mathbf{2 0}$ & - & $\mathbf{8 0}$ & - \\
\hline I & $\mathbf{5 0}$ & - & - & $\mathbf{5 0}$ \\
\hline J & $\mathbf{4 0}$ & - & - & $\mathbf{6 0}$ \\
\hline K & $\mathbf{3 0}$ & - & - & $\mathbf{7 0}$ \\
\hline L & $\mathbf{2 0}$ & - & - & $\mathbf{8 0}$ \\
\hline
\end{tabular}

\section{Cell trays:}

Cell trays are used by commercial growers to produce seedlings for planting out. The seedlings are easily removed from the tray for transplanting, and the growth check to transplants from cell trays is minimal when planted in the field, compared to the use of other types of transplants. The dimensions of trays was $(40 \times 80 \mathrm{~cm})$ and $(11 \times 19$ cells $)$. The trays were made from foam.

\section{METHODS}

Saturated hydraulic conductivity "Ks":

Saturated hydraulic conductivity "Ks" $(\mathrm{cm} / \mathrm{h})$ of the media samples were measured (three replicates per treatment) using the constant head method as described by Stolte (1997).

\section{Real density, bulk density, and total porosity:}

Dry bulk density $\left(\mathrm{g} / \mathrm{cm}^{3}\right)$ was calculated (dry weight basis) for each sample by weighting $400 \mathrm{ml}$ of beakers filled with the soil mixture. 
Samples were oven dried at $105^{\circ}$ for 24 hour, and weighted again. The bulk density was determined as dry soil mass per media volume. Real density $\left(\mathrm{g} / \mathrm{cm}^{3}\right)$, bulk density $\left(\mathrm{g} / \mathrm{cm}^{3}\right)$, and total porosity $(\%)$ were determined according to klute (1988).

\section{Moisture holding capacity:}

Moisture holding capacity was measured on a dry weight basis according to the following equation (Thomposetal. 2008):

$$
\text { M. H.C. }=\frac{M_{f}-M_{d}}{M_{d}}
$$

\section{Where:}

M. H.C. : is moisture holding capacity $(g / g)$,

$\boldsymbol{M}_{\boldsymbol{f}}$ : is the mass $(g)$ of the sample at field capacity, and

$\boldsymbol{M}_{\boldsymbol{d}}$ : is the mass $(g)$ of the dry sample.

\section{RESULTS AND DISCUSSION}

The main objective of this study was possibility use some agriculture residuals as nursery media. The ground cotton stalks, ground rice straw, and ground cornstalks with sand ratio were mixed to give media, some physical properties and watering characteristics of different media samples were determined and their effects on growth parameters of tomato nursery.

\section{Water characteristics of different media:}

Fig. (1) Shows that total porosity (\%) is affected by residuals ratio. In this figure the total porosity was increased from 56 to $73 \%$, from 66 to $80 \%$, and from 64 to $77 \%$ at increased of residuals ratio from 50 to $80 \%$, at used ground cotton stalks, ground rice straw, and ground cornstalks respectively. These results were agreement with CH Yang et al. (2010).

Fig. (2) illustrated that the relation between available water (\%) and residuals ratio (\%) at different residuals matter. Generally at increased of residuals ratio from 50 to $80 \%$ the available water increased from 6.9 to $8.4 \%$, from 6.8 to $9.2 \%$, and from 6.9 to $8.5 \%$ at used ground cotton stalks, ground rice straw, and ground cornstalks respectively. 


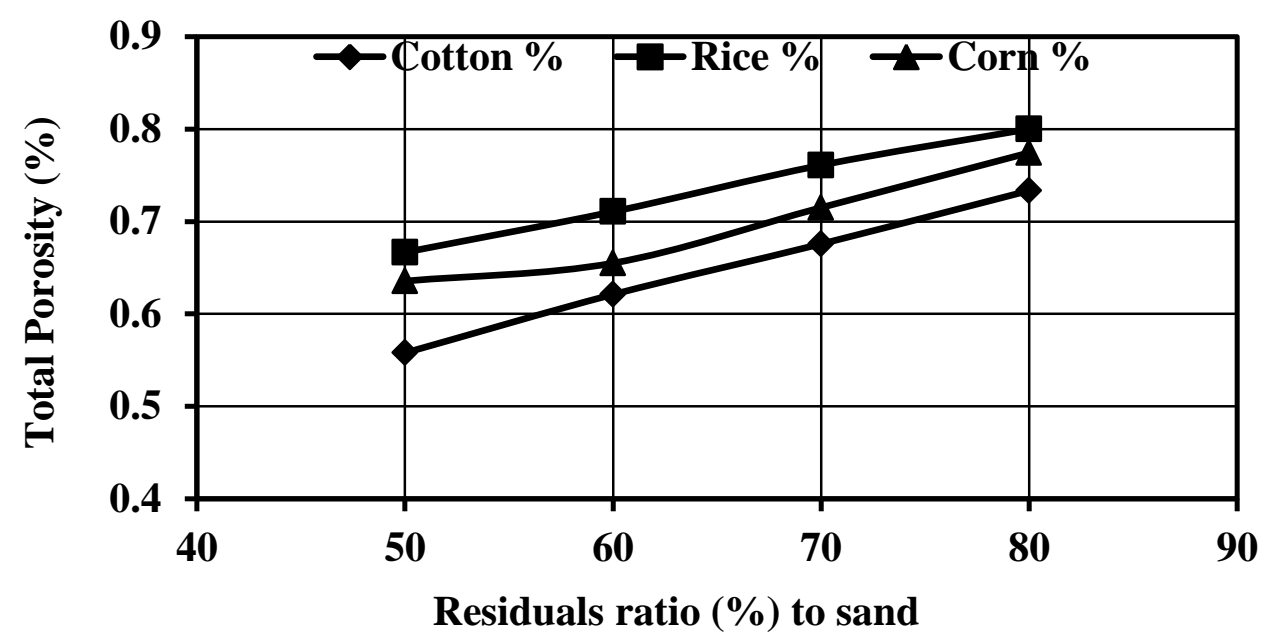

Fig. (1): Relation between total porosity (\%) and residuals ratio (\%) at different residuals matter.

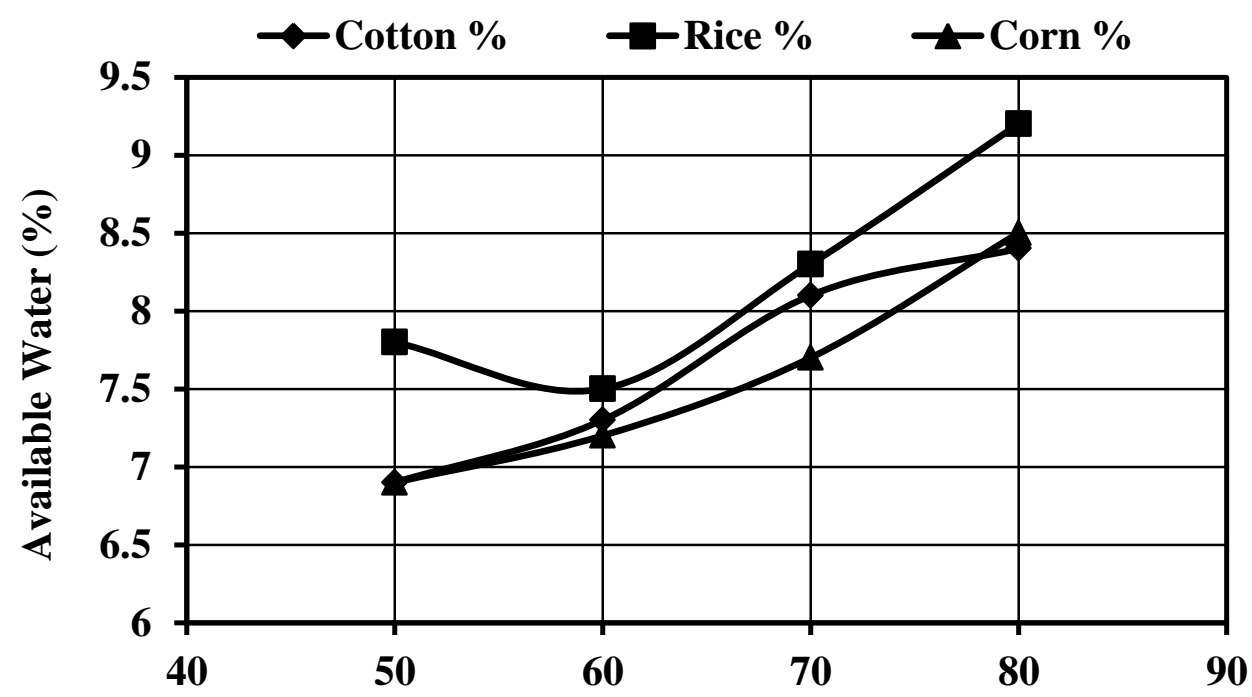

Residuals ratio (\%) to sand

Fig. (2): Relation between Available Water (\%) and residuals ratio (\%) at different residuals matter.

Fig. (3) illustrated that the relation between germination ratio (\%) and residuals ratio (\%) at different residuals matter, by increased of residuals ratio from 50 to $80 \%$ the germination ratio (\%) increased from 57.4 to 
$79.4 \%$, from 69 to $90 \%$, and from 51 to $76 \%$ at used ground cotton stalks, ground rice straw, and ground cornstalks respectively.

Fig. (4) Shows that plant weight (g/plant) is affected by residuals ratio. In this figure the plant weight (g/plant) was increased from 0.42 to 0.55 $\mathrm{g} / \mathrm{plant}$, from 0.53 to $0.80 \mathrm{~g} / \mathrm{plant}$, and from 0.66 to $0.75 \mathrm{~g} / \mathrm{plant}$ at increased of residuals ratio from 50 to $80 \%$, at used ground cotton stalks, ground rice straw, and ground cornstalks respectively.

Fig. (5) Illustrated that the relation between nursery high $(\mathrm{cm} /$ nursery) and residuals ratio (\%) at different residuals matter. Generally at increased of residuals ratio from 50 to $80 \%$ the nursery high (cm/nursery) increased from 4.05 to 5.73 (cm/nursery), from 4.75 to 6.78 ( $\mathrm{cm} /$ nursery), and from 4.9 to $5.93(\mathrm{~cm} /$ nursery) at used ground cotton stalks, ground rice straw, and ground cornstalks respectively.

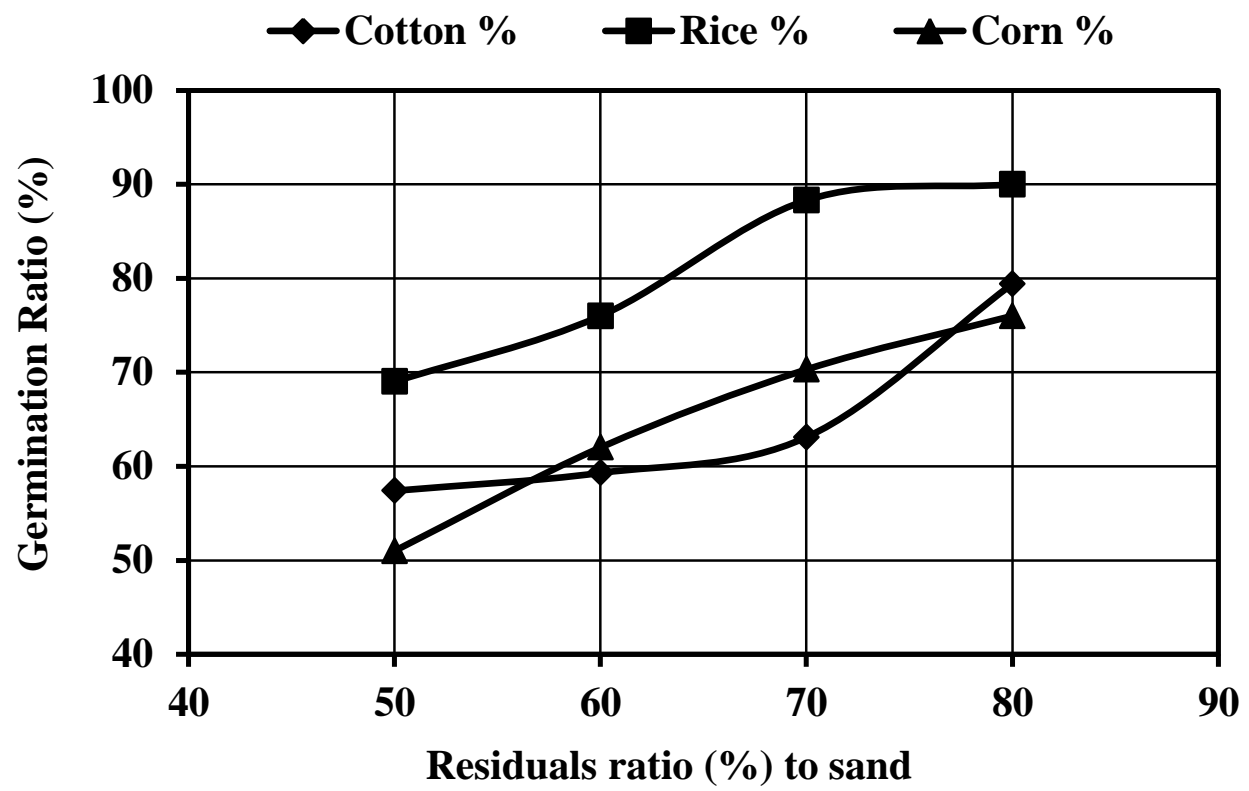

Fig. (3): Relation between Germination Ratio (\%)and residuals ratio (\%) at different residuals matter. 


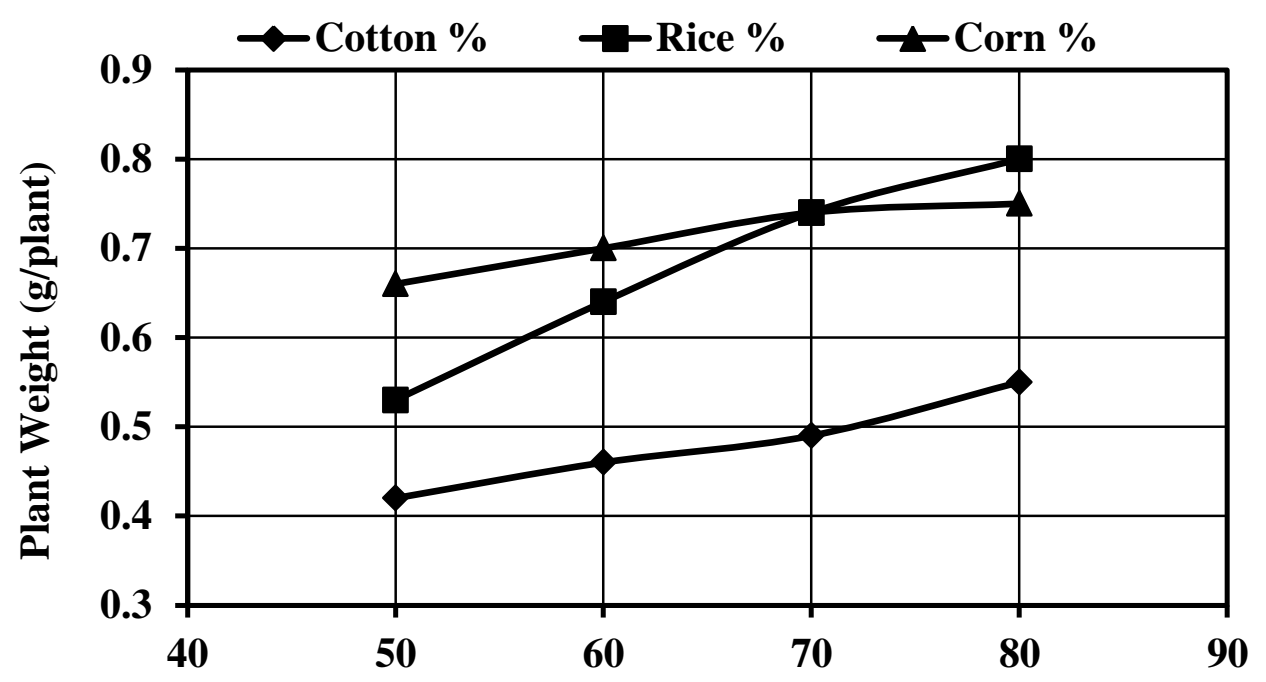

Residuals ratio (\%) to sand

Fig. (4): Relation between Plant Weight (g/plant) and residuals ratio (\%) at different residuals matter.

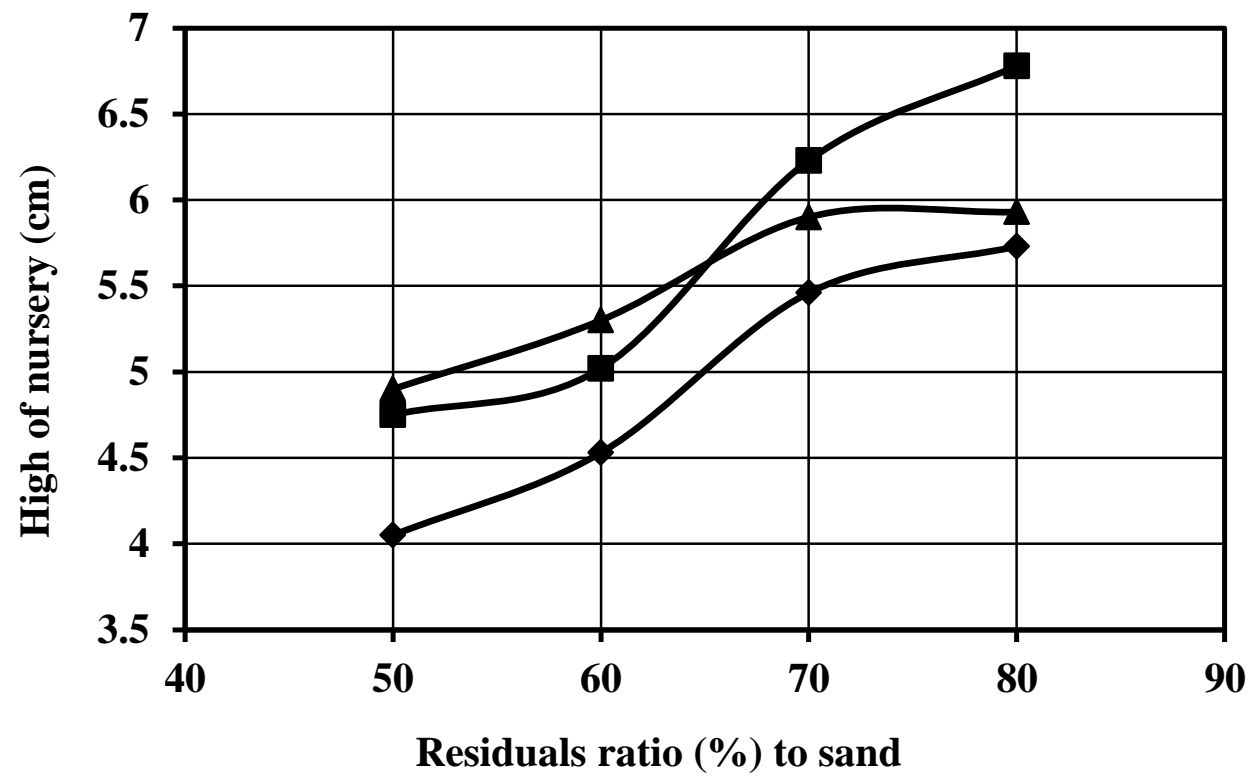

Fig. (5): Relation between high of nursery $(\mathrm{cm})$ and residuals ratio (\%) at different residuals matter. 


\section{CONCLUSION}

Generally for the all treatments, by decrease of coarse sand from $50 \%$ to $20 \%$ and increase the residuals ratio from $50 \%$ to $80 \%$ as a ratio in media, the total porosity (\%), available water (water holding capacity) (\%) were increased. Meanwhile, the real density $\left(\mathrm{g} / \mathrm{cm}^{3}\right)$, bulk density $\left(\mathrm{g} / \mathrm{cm}^{3}\right)$ and hydraulic conductivity $(\mathrm{cm} / \mathrm{min})$ were decreased. The growth parameters as germination ratio $(\%)$, nursery high $(\mathrm{cm})$, leaves number, and plant weight were increased.

\section{REFERENCES}

Abd El-Gaffar, E. A., (1987). Planning of agricultural structures, $1^{\text {st }}$. ed., El-Shatby Center for publishing and distribution, Laskareds Street, Ghapreyal-Ramel, Alexandria, ARE: 390 (in Arabic).

Alaa El-Din, M. N., S. A.; El-Shami, M. H.; Mahmoud, and A. M. Abdel Aziz, (1983).Biogas for Egyptian villages (Energy fertilizer - forage) Soil and water research institute, Agri. Research Center: 257 (in Arabic).

CH Yang, TK Kim., JH Ryu, SB Lee, S Kim, NH Baek, WY Choi, and SJ Kim (2010). Effect of rice straw application on Soil Physico-chemical Properties.World Congress of Soil Science, Soil Solutions for a Changing World,Brisbane, Australia, Published on DVD.pp 15.

El-Zahaby, M. A. (1996). Techno-economic study on utilization ofsome field crop residues, M.Sc., Thesis, Agric. Eng., Faculty of Agric., Cairo Univ.: 2 - 10, 218 - 223 (in Arabic).

FAO, (1989).Producton year. Vol:43. FAO. Rome.

FAO, (2005).Quqrterly bulletin of statistics, New York.

Klute, A., (1988). Methods of soil analysis part 1 "physical mineralogical methods" 2rd AD., Am. SocityAgrony monograph N9 Madison, Wisconsin, USA. 
Nouno, S. (2003).Alocal professor wants to turn Cairo's burning rice fields into building panels.http://www.businesstodayegypt.com/issues /0209/3E09/02093E09p.asp

Stolte, J., (1997).Determination of the saturated hydraulic conductivity using the constant head method.Manual for soil physical measurements. Version: 3, pp 77. DLO, winand staring center.Wageningen.The Nether Lands.

Thompson A. M., A. C. Paul, and N. J. Balster, (2008).Physical and hydraulic properties of engineered soil media for Bioetention Basins. Trans. Of the ASABE.Vol: 51 (2): 499 - 514.

Villareal, R. L., (1978).First international Symposium on Tomato AVRDC, shahua, Tainan, Taiwan, China.

Zabady, F. I., (2012). Effect of phsico-hydraulic properties on tomato nursery.Misr J. Ag. Eng., Vol.: 29 (1): $179-192$.

\section{الملخص العربي}

إمكانية استخدام بعض المخلفات الزراعية فى إنتاج شتخلات الطماطم المريع

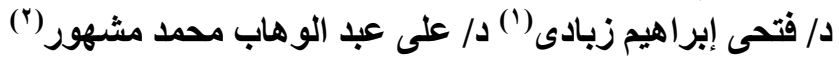

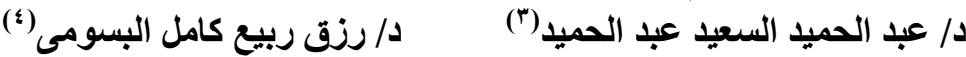

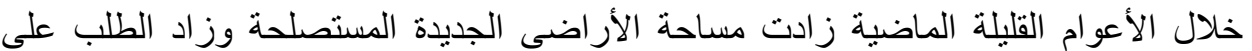

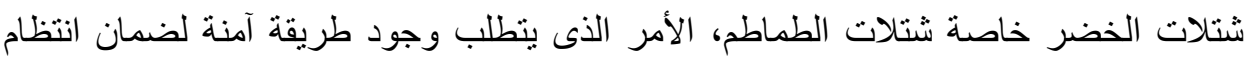

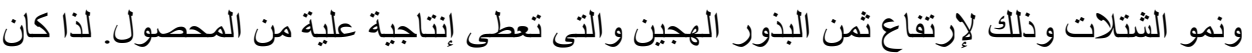

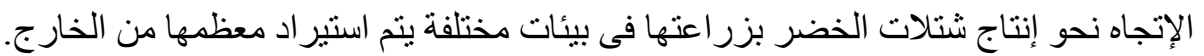
ويهدف هذا البحث إلى دراسة إمكانية استخدام بعض المخلفات الزر اعبة النية النباتية مثل حطب القطن المطحون وقش الأرز المطحون وكذلك حطب الذرة المطحون وذلك لإنتاج شتلات جيدة من

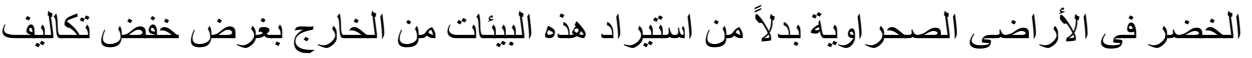

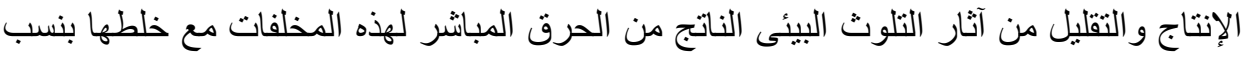

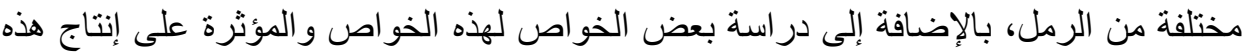

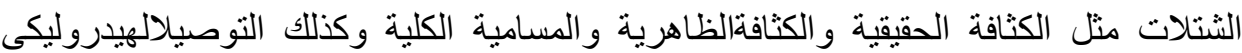
و السعة الحقلية ونقطة الذبول الدائمة و علاقة ذلك بكمية الرطوبة التى تحتفظ بها هذه التربة.

(1) أستاذ مساعد بقسم هندسة نظم المياه والرى - كلية الهندسة الزراعية بالقاهرة - جامعة الأزهر.

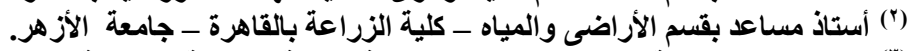

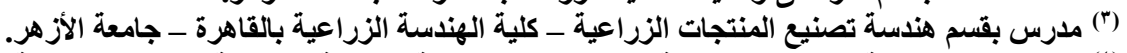

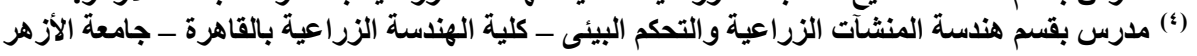


كما تم در اسة بعض محددات النمو على الشتلات وذللك بزر اعة هذه الشتلات فى صو انى عبارة

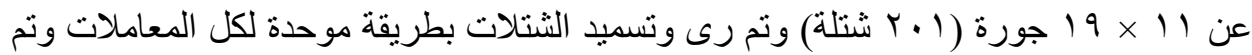

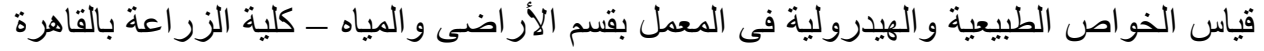

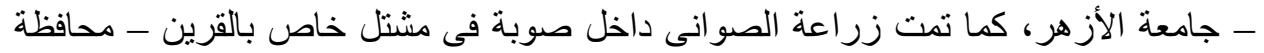

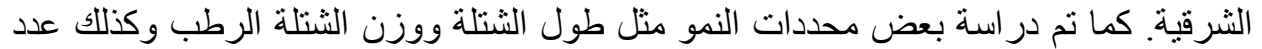

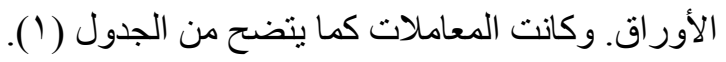

\section{وكاتت النتائج كما يلى:}

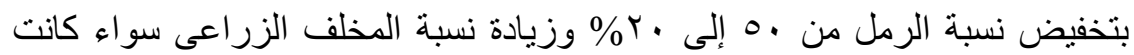

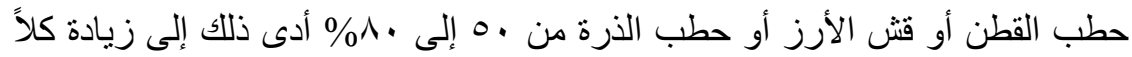
من المسامية الكلية (\%) من هـ

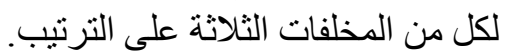

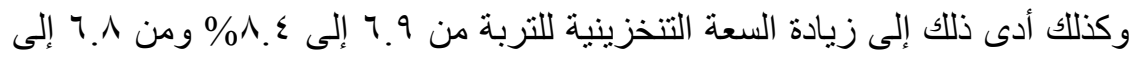

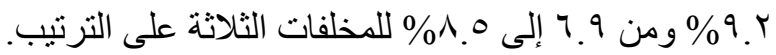

\begin{tabular}{|c|c|c|c|c|}
\hline \multicolumn{4}{|c|}{ نسب الخلط } & \multirow{3}{*}{ المعاملة } \\
\hline الأرة & الأرز & القطن & الرمل & \\
\hline$(\%)$ & $(\%)$ & $(\%)$ & $(\%)$ & \\
\hline- & - & 0. & 0. & A \\
\hline- & - & 7. & $\varepsilon$. & B \\
\hline- & - & $v \cdot$ & $r$. & $\mathbf{C}$ \\
\hline- & - & $\Lambda$. & $r$. & D \\
\hline- & 0 . & - & 0. & $\mathbf{E}$ \\
\hline - & 7. & - & $\varepsilon$. & $\mathbf{F}$ \\
\hline- & $V$. & - & $r$. & $\mathbf{G}$ \\
\hline - & $\Lambda$. & - & $r$. & $\mathbf{H}$ \\
\hline 0. & - & - & 0. & I \\
\hline 7. & - & - & $\varepsilon$. & $\mathbf{J}$ \\
\hline V. & - & - & $r$. & $\mathbf{K}$ \\
\hline$\Lambda$. & - & - & $r$. & $\mathbf{L}$ \\
\hline
\end{tabular}

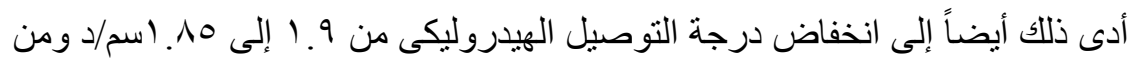
AV أما بالنسبة لمحددات النمو فكانت النتائج كما يلح:

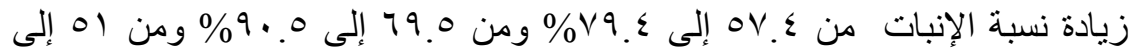
\% و ذللك للمخلفات الثلاثة على الترنيب. 


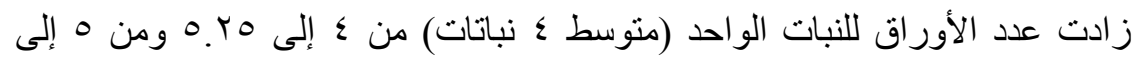

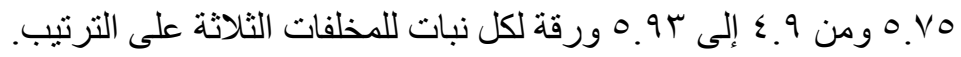

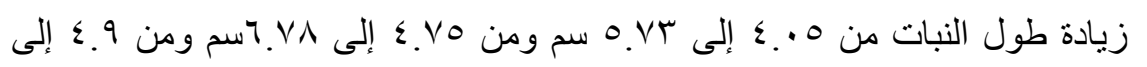

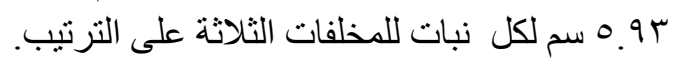

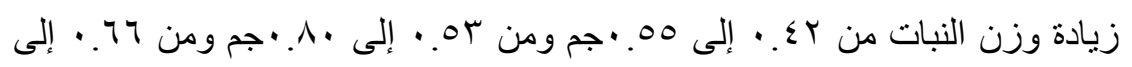

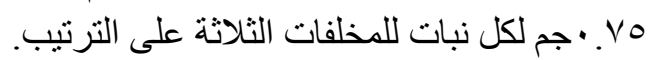

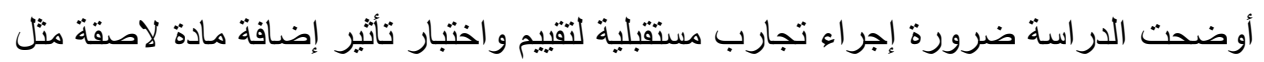

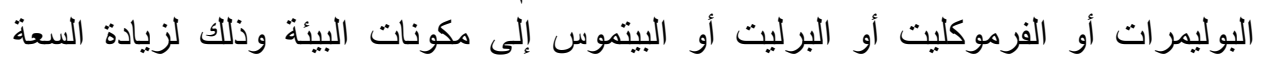

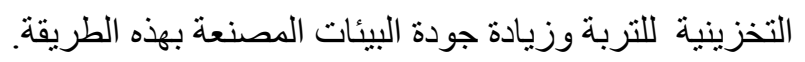

